\title{
The functional and molecular characterisation of human embryonic stem cell-derived insulin-positive cells compared with adult pancreatic beta cells
}

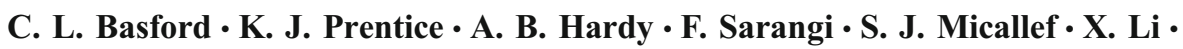 \\ Q. Guo • A. G. Elefanty • E. G. Stanley • G. Keller • E. M. Allister • M. C. Nostro •
}

M. B. Wheeler

Received: 24 June 2011 / Accepted: 5 September 2011 /Published online: 11 November 2011

(C) Springer-Verlag 2011

\begin{abstract}
Aims/hypothesis Using a novel directed differentiation protocol, we recently generated up to $25 \%$ insulinproducing cells from human embryonic stem cells (hESCs) (insulin $^{+}$cells). At this juncture, it was important to functionally and molecularly characterise these hESCderived insulin ${ }^{+}$cells and identify key differences and similarities between them and primary beta cells.

Methods We used a new reporter hESC line with green fluorescent protein (GFP) cDNA targeted to the INS locus by homologous recombination $\left(I N S^{G F P / w}\right)$ and an
\end{abstract}

C. L. Basford, K. J. Prentice and A. B. Hardy contributed equally to this study.

Electronic supplementary material The online version of this article (doi:10.1007/s00125-011-2335-x) contains peer-reviewed but unedited supplementary material, which is available to authorised users.

C. L. Basford · K. J. Prentice · M. B. Wheeler

Division of Cellular and Molecular Biology,

Toronto General Research Institute, TMDT,

Toronto, ON, Canada

A. B. Hardy $\cdot$ Q. Guo $\cdot$ E. M. Allister $(\triangle) \cdot$ M. B. Wheeler

Endocrinology and Diabetes Research Group,

Department of Physiology, University of Toronto,

1 King's College Circle (Room 3352),

Toronto, ON, Canada M5S 1A8

e-mail: emma.allister@utoronto.ca

F. Sarangi $\cdot$ G. Keller $\cdot$ M. C. Nostro $(\bowtie)$

McEwen Centre for Regenerative Medicine, TMDT,

8th Floor, Room 8-301, 101 College St.,

Toronto, ON, Canada M5G 1 L7

e-mail: cnostro@uhnresearch.ca

S. J. Micallef $\cdot$ X. Li • A. G. Elefanty $\cdot$ E. G. Stanley

Monash Immunology and Stem Cell Laboratories,

Monash University,

Melbourne, Victoria, Australia untargeted hESC line (HES2). INS $S^{G F P / w}$ allowed efficient identification and purification of GFP-producing (INS: $\mathrm{GFP}^{+}$) cells. Insulin ${ }^{+}$cells were examined for key features of adult beta cells using microarray, quantitative PCR, secretion assays, imaging and electrophysiology.

Results Immunofluorescent staining showed complete colocalisation of insulin with GFP; however, cells were often multihormonal, many with granules containing insulin and glucagon. Electrophysiological recordings revealed variable $\mathrm{K}_{\text {ATP }}$ and voltage-gated $\mathrm{Ca}^{2+}$ channel activity, and reduced glucose-induced cytosolic $\mathrm{Ca}^{2+}$ uptake. This translated into defective glucose-stimulated insulin secretion but, intriguingly, appropriate glucagon responses. Gene profiling revealed differences in global gene expression between INS: $\mathrm{GFP}^{+}$cells and adult human islets; however, INS:GFP ${ }^{+}$cells had remarkably similar expression of endocrine-lineage transcription factors and genes involved in glucose sensing and exocytosis.

Conclusions/interpretation INS:GFP ${ }^{+}$cells can be purified from differentiated $\mathrm{hESCs}$, providing a superior source of insulin-producing cells. Genomic analyses revealed that INS:GFP ${ }^{+}$cells collectively resemble immature endocrine cells. However, insulin ${ }^{+}$cells were heterogeneous, a fact that translated into important functional differences within this population. The information gained from this study may now be used to generate new iterations of functioning beta cells that can be purified for transplant.

Keywords Beta cells · Calcium · Electron microscopy Electrophysiology · Glucagon secretion · Insulin secretion . Microarray $\cdot$ Stem cells

$\begin{array}{ll}\text { Abbreviations } & \\ \text { ARX } & \text { Aristaless related homeobox } \\ \text { BRN4 } & \text { Brain-specific homeobox/POU domain } \\ & \text { protein } 4\end{array}$




$\begin{array}{ll}\text { CK19 } & \text { Cytokeratin 19 } \\ \text { d22-HES2 } & \text { Day 22 differentiated HES2 } \\ \text { GFP } & \begin{array}{l}\text { Green fluorescent protein } \\ \text { HES2 }\end{array} \\ \text { UEStargeted hESC } \\ \text { INS }\end{array}$

\section{Introduction}

Type 1 diabetes results from an autoimmune attack on pancreatic beta cells leading to insulin deficiency. Improvements have been made in islet transplantation [1], but problems remain, including low donor numbers and cell loss during islet isolation [2]. The generation of beta cells from human embryonic stem cells (hESCs) could offer an unlimited source of insulin-producing cells for transplantation. Pancreatic cells, including those expressing insulin, can be generated in vitro from hESCs; however, cells develop with low efficiency in heterogeneous cultures, are mostly polyhormonal and have a poorly defined phenotype [3-8]. We hypothesise that understanding the functional nature of in vitro generated endocrine cells and identifying key molecular differences between them and adult beta cells represent important steps towards the generation of functional beta cells suitable for transplantation.

Previously, D'Amour and colleagues generated insulinproducing cells from hESCs (insulin ${ }^{+}$cells) using a five-stage differentiation protocol [8]. These insulin ${ }^{+}$cells released Cpeptide in response to secretagogues, such as $\mathrm{KCl}$; however, they were not glucose-responsive and C-peptide content was $\sim 50 \%$ lower than in human islets, suggesting poor glucose sensing and/or improper insulin processing. More recently, the same group from ViaCyte transplanted hESC-derived pancreatic progenitors (hormone-negative cells) into the fat pads of immunocompromised mice [9]. Maximal insulin secretion occurred 3 months post-implantation, when the mice had plasma human C-peptide levels comparable to those in mice implanted with $\sim 4,000$ human islets. Graft analysis following in vivo differentiation showed that hESCderived pancreatic progenitors generated beta-like cells that co-produced pancreatic and duodenal homeobox 1 (PDX1), NK6 homeobox 1 (NKX6-1) and insulin independently of other hormones; however, mice became hypoglycaemic during glucose tolerance testing, suggesting that insulin secretion was indiscriminate. In addition, the same hESCderived pancreatic progenitors transplanted into athymic nude rats failed to produce substantial numbers of beta-like cells [10]. Collectively, this suggests that much progress is still required in the derivation of beta cells from hESC.

We recently developed and characterised a 22-day differentiation protocol that more efficiently generates insulin-producing cells from hESCs [11] (Fig. 1a). The availability of hESCs with green fluorescent protein (GFP) cDNA targeted to the insulin (INS) locus by homologous recombination $\left(I N S^{G F P / w}\right)$ allowed us to isolate pure insulin ${ }^{+}$ populations or identify them in mixed cultures (Fig. 1b). Here we have extensively defined the functional, molecular and phenotypic characteristics of day 22-differentiated

a

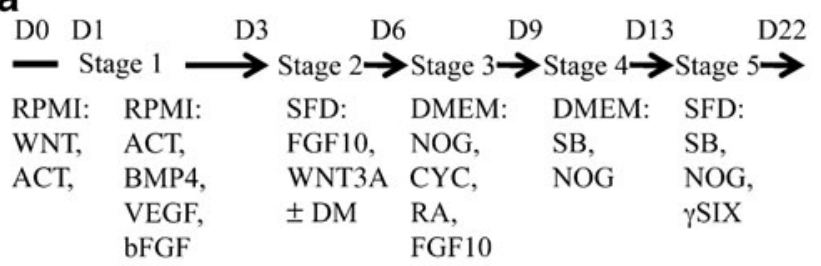

b
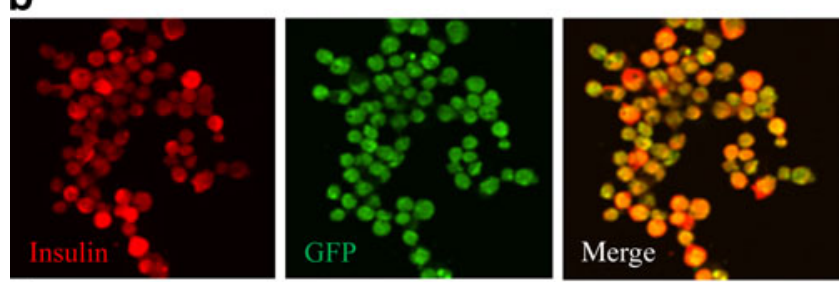

C
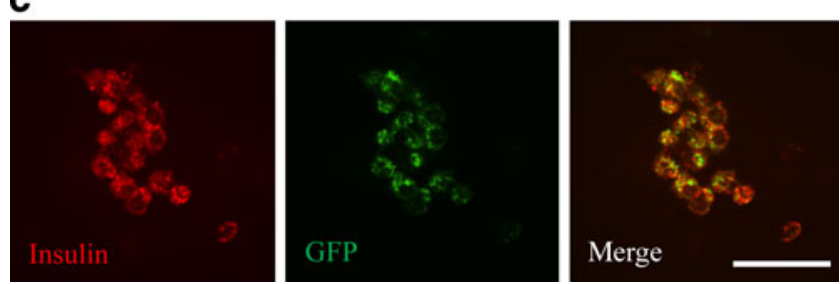

Fig. 1 hESCs were differentiated into insulin ${ }^{+}$cells. a The 22 day 'Nostro protocol' for hESC differentiation into endocrine cells is divided into five stages; the growth factors, medium and duration of each stage are shown. ACT, activin A; bFGF, basic fibroblast growth factor; BMP4, bone morphogenetic protein 4; CYC, KAADcyclopamine; DM, dorsomorphin; FGF10, fibroblast growth factor 10; NOG, noggin; SFD, serum free differentiation media; RA, alltrans retinoic acid; SB, SB 431542; $\gamma$ SIX, $\gamma$-secretase inhibitor X, L-685,458; VEGF, vascular endothelial growth factor; WNT, integration 1 wingless. b Immunostaining for insulin in INS:GFP ${ }^{+}$ cells and (c) in adult murine beta cells isolated from MIP-GFP mice demonstrated $100 \%$ co-localisation with GFP. Scale bar, $50 \mu \mathrm{m}$ 
insulin $^{+}$cells compared with murine beta cells and human islets. Although there are differences, a subset of insulin ${ }^{+}$ cells share many characteristics with mature beta cells, including some insulin-like granules, ion channel activity and intracellular calcium responsiveness, allowing optimism with regard to the generation of fully functioning beta cells in vitro.

\section{Methods}

hESC culture

$I N S^{G F P / w}$ and untargeted hESC (HES2) cell lines (ES Cell International, Singapore) approved by the Stem Cell Oversight Committee were differentiated for 22 days using the 'Nostro protocol' [11] (Fig. 1a); HES2 cells differentiated for 22 days are referred to as day 22 differentiated HES2 (d22-HES2). Following differentiation, INS $S^{G F P / w}$ were FACS-sorted into GFP-producing (INS:GFP ${ }^{+}$) and GFPnegative (INS:GFP') fractions [11].

Islet isolation and dispersion

Mouse insulin promoter driving GFP expression (MIPGFP) mice were a gift from M. Hara (Endocrinology, Diabetes and Metabolism, University of Chicago, Chicago IL, USA). Principles of laboratory animal care were followed and protocols were approved by the University of Toronto Animal Care Committee. Human islets from healthy donors were isolated using the Edmonton protocol [1] and provided by the ABCC Human Islet Distribution Program (University of Alberta, Edmonton AB, Canada). Donation was approved by the local institutional review board. Islets were dispersed as previously described [12].

\section{Immunofluorescent staining}

The percentage of mono- and polyhormonal d22-HES2 cells was determined using confocal microscopy and colocalisation software (ImageJ, NIH, Bethesda ML, USA). Cell maturity was determined by expression of immature beta cell markers. The antibodies used are detailed in electronic supplementary material (ESM) Table 1. Staining was performed as previously described [13, 14]. Images were acquired using a confocal microscope (Quorum Wave FX Spinning Disc; Perkin Elmer, Waltham ML, USA) and Volocity software (Perkin Elmer).

Molecular analysis

Microarray Total RNA was extracted from INS: $\mathrm{GFP}^{+}$and INS: $\mathrm{GFP}^{-}$fractions, and human islets using a kit (RNeasy mini; Qiagen, Hilden, Germany). Microarray analysis was performed as previously described [15] using the U133 Plus 2.0 Gene Chip (Affymetrix, Santa Clara, CA, USA) at the University Health Network Microarray Centre (Toronto, ON, Canada). Data were summarised and normalised with the robust multi-array method using a software package (Affymetrix Expression Console; Affymetrix). The lowest $20 \%$ of robust multi-array values were considered background fluorescence and removed. Significant differences were defined as a twofold or greater change in expression at $p<0.05$. Heat maps were generated using the Multi-Experiment Viewer (Dana-Farber Cancer Institute, Boston MA, USA). Hierarchical clustering was performed using Pearson's correlation with average linkage clustering. Significantly changed genes were functionally classified using the DAVID database and clustered on the basis of GOTERM_MF 2 (http://david.abcc.ncifcrf.gov/, accessed 1 May 2011). Data are compatible with MIAME 2.0 (http:// www.mged.org/Workgroups/MIAME/miame.html, accessed 1 May 2011).

Quantitative PCR Quantitative PCR was performed as previously described [12] on the same samples used for microarray. Primers are listed in ESM Table 2.

\section{Electron microscopy}

D22-HES2 cells were fixed and analysed as previously described [16]. Granule morphology was manually quantified [17, 18]. Immunogold staining with insulin and glucagon antibodies (ESM Table 1) was performed on purified INS: $\mathrm{GFP}^{+}$cells as previously described [19].

Hormone secretion and analysis of the secretion-coupling apparatus

Hormone secretion from d22-HES2 cells or islets was assessed as previously described $[12,17]$. Hormone concentrations were measured in the cells and supernatant fraction using a RIA kit (Cedarlane Labs, Burlington, ON, Canada). Electrophysiological analysis of $\mathrm{K}_{\mathrm{V}}, \mathrm{K}_{\mathrm{ATP}}, \mathrm{Ca}_{\mathrm{V}}$ and $\mathrm{Na}^{+}$ currents in INS: $\mathrm{GFP}^{+}$(within heterogenous cultures) and islet cells was performed as previously described [12, 20]. Voltage clamp protocols are illustrated in ESM Figs 1-4. Intracellular $\mathrm{Ca}^{2+}$ was measured in INS:GFP ${ }^{+}$cells and dispersed human islets loaded with Fura2-AM (Molecular Probes, Carlsbad CA, USA) as previously described [12].

\section{Transplantation}

Purified INS:GFP ${ }^{+}$cells were transplanted into NODSCID $-\gamma$ mice and grafts analysed 1 month later. Details are provided in the ESM Methods. 
Statistical analysis

Data are expressed as mean \pm SEM. Statistical analysis was performed using a two-tailed student's $t$ test or ANOVA. Statistical significance was assigned at $p<0.05$.

\section{Results}

Molecular analysis

We first used transcriptional profiling to characterise the INS:GFP ${ }^{+}$cells. Grouped comparisons with INS:GFP ${ }^{-}$ cells were used to determine the commitment of INS: $\mathrm{GFP}^{+}$cells to an endocrine lineage, while comparison with human islets was used to determine the global relationship of our INS: $\mathrm{GFP}^{+}$cells with mature endocrine cells $(n=3$ per group).

INS:GFP ${ }^{+}$compared with INS:GFP cells Global analysis of INS: $\mathrm{GFP}^{+}$compared with INS: $\mathrm{GFP}^{-}$fractions revealed that $5.8 \%$ of genes were changed by two-fold or greater (up- or downregulation, $p<0.05$; ESM Fig. 5a). Interestingly, the greatest changes were in genes associated with protein binding, including genes for extracellular matrix proteins (collagens), receptors (IGFIR and GABRB3), proteases (DPP4 and the MMP family), cell cycle proteins (MAD2 [also known as MAD2L1] and CCNA2) and cell adhesion proteins $(\mathrm{CDH} 2)$. To determine endocrine commitment of the INS:GFP ${ }^{+}$fraction, 128 genes involved in pancreatic development, metabolism, insulin exocytosis, ion channels and pancreatic hormones [21, 22] were examined (Fig. 2a, b and ESM Fig 6a).

The transcriptional regulators $N O T C H$ (also known as NOTCH1), CDX2, SOX2 and SOX9, all of which are involved in early endoderm specification [21, 23], showed higher expression in the INS: $\mathrm{GFP}^{-}$than in the INS:GFP ${ }^{+}$ fraction (Fig. 2b), whereas transcription factors of the endocrine signature, e.g. NEUROD1, ISL1, MAFB and PAX6 $[15,24]$, were higher in the INS:GFP ${ }^{+}$than in the INS:GFP ${ }^{-}$fraction (Fig. 2b). INS: $\mathrm{GFP}^{+}$cells expressed more INS than INS:GFP ${ }^{-}$cells; however, we also observed increased $G C G$ and $S S T$, but reduced GHRL (Fig. 2b). Together, this suggests that the INS: $\mathrm{GFP}^{+}$fraction more strongly resembled endocrine lineage cells than the INS: $\mathrm{GFP}^{-}$fraction.

To further confirm this, we investigated genes involved in endocrine cell function. $\mathrm{K}_{\mathrm{ATP}}$ channels are expressed in alpha and beta cells, and are required for normal secretory function in both cell types [25]. We examined genes encoding the major subunits of these channels and found increased expression of $A B C C 8$ (protein name SUR1) and KCNJ11 (protein name $\mathrm{K}_{\mathrm{ir}} 6.2$ ) in INS:GFP ${ }^{+}$compared with
Fig. 2 Expression of genes associated with pancreatic development and islet function with hierarchical cluster analysis. The INS:GFP expression profile was compared with INS:GFP ${ }^{-}$and human islets. a Heat map showing the background-corrected robust multi-array expression values of 128 endocrine lineage genes of interest from three sample sets of human islets, INS:GFP ${ }^{+}$and INS:GFP ${ }^{-}$cells. Hierarchical clustering was determined using Pearson correlation distance metric with average linkage clustering. Of the 128 genes of interest, (b) 28 were significantly changed between the INS:GFP ${ }^{+}$and INS:GFP ${ }^{-}$populations, and (c) 23 were significantly changed between the INS:GFP ${ }^{+}$and human islet populations. Significance was defined as a two-fold or greater increased or decreased expression, $p \leq 0.05$

INS:GFP ${ }^{-}$cells (Fig. 2b). Oscillations of $\mathrm{Ca}^{2+}$ levels in endocrine cells are crucial for hormone secretion: in alpha cells $\mathrm{N}$ - and $\mathrm{P} / \mathrm{Q}$-type $\mathrm{Ca}^{2+}$ channel activity is most important for glucagon release [26], whereas in beta cells, L-type $\mathrm{Ca}^{2+}$ channels predominate [27]. We found levels of the L-type $\mathrm{Ca}^{2+}$ channel $\mathrm{Ca}_{V} 1.3$ were higher in the INS: $\mathrm{GFP}^{+}$fraction than in INS: $\mathrm{GFP}^{-}$fraction, with levels of other channel subtypes being similar (ESM Fig. 6a).

Glucokinase is rate-limiting for glucose metabolism in islet cells [28] and expression of its gene was significantly higher in INS:GFP ${ }^{+}$than in INS:GFP ${ }^{-}$cells. A key gene required for insulin biosynthesis and processing, SLC30A8 (also known as ZnT8) [18] was also significantly elevated, along with many components of the exocytotic machinery (SNAP25, STX1A, STXBP1 and SYT4) [29], suggesting an increased capacity for hormone exocytosis. Interestingly, synaptophysin $(S Y P)$, an islet surface marker [30], was more highly expressed in the INS:GFP ${ }^{+}$than in the INS: $\mathrm{GFP}^{-}$fraction (Fig. $2 \mathrm{~b}$ and ESM Fig. 6a).

INS: $\mathrm{GFP}^{+}$cells compared with human islets Global analysis of INS: $\mathrm{GFP}^{+}$cells compared with human islets revealed that $14.4 \%$ of genes were changed by twofold or greater (up- or down-regulation, $p<0.05$; ESM Fig. 5b). Approximately $50 \%$ of significantly changed genes in the INS: $\mathrm{GFP}^{+}$fraction encoded proteins involved in protein- or ion-binding. The ion-binding category includes genes involved in ion transport (e.g. $\mathrm{Na}^{+} / \mathrm{H}^{+}$exchangers and $\mathrm{K}^{+}$ channels, including KCNJ11), transcription factors (zincfinger proteins) and amino acid transporters (SLC7A8). The same 128 genes of interest examined above were compared in INS: GFP ${ }^{+}$cells and human islets (Fig. 2a, c and ESM Fig. 6b).

Endoderm specification genes were expressed at similarly low levels in INS: $\mathrm{GFP}^{+}$cells and human islets, indicating maturity beyond this developmental stage. Expression of a cluster of transcription factors following $N G N 3$ (also known as NEUROG3)-dependent endocrine commitment (NEUROD1, ISL1, PAX6, PROX1 and MAFB) 


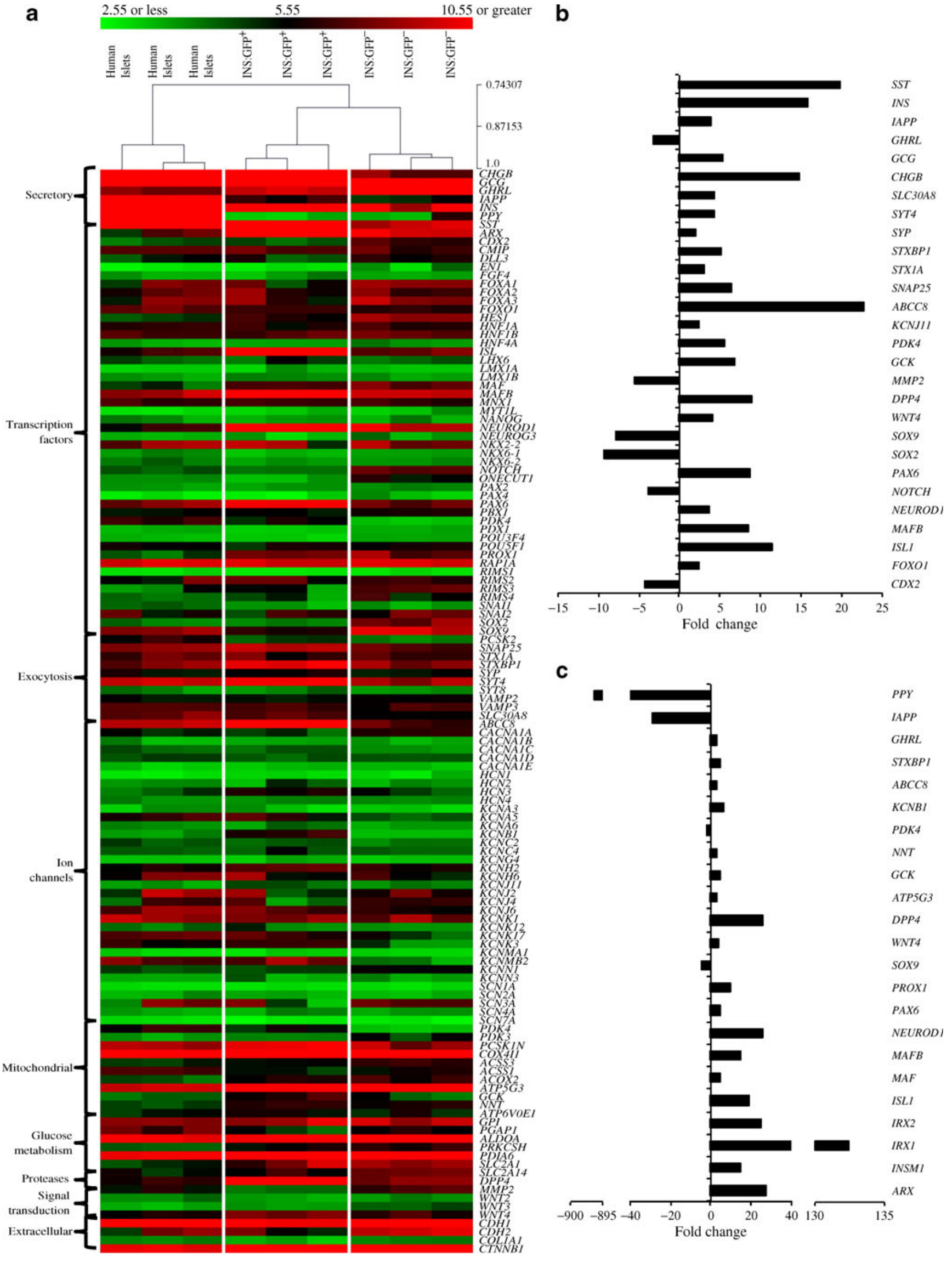


was significantly increased in INS: $\mathrm{GFP}^{+}$cells compared with human islets, although many, including $P A X 4$, were expressed at similar levels (Fig. 2c and ESM Fig. 6b). Microarray analysis showed that NKX6-1 expression was 1.45 -fold lower in INS: $\mathrm{GFP}^{+}$cells than in human islets, this difference being significant by quantitative PCR (Fig. 2a and ESM Fig. 6b, 7). In addition, the expression of beta cell-specific transcription factors such as INSMI and MAF were higher in INS:GFP ${ }^{+}$cells, while alpha cell lineage transcription factors $I R X 1$ and $A R X[30,31]$ were also markedly increased. INS, GCG and SST were expressed at the maximum level detectable by microarray in the INS: $\mathrm{GFP}^{+}$and human islet fractions, while $P P Y$ and IAPP expression was lower in INS: $\mathrm{GFP}^{+}$cells than in human islets (Fig. 2c). Quantitative PCR analysis revealed that $I N S, G C G$ and $S S T$ expression was in fact significantly a
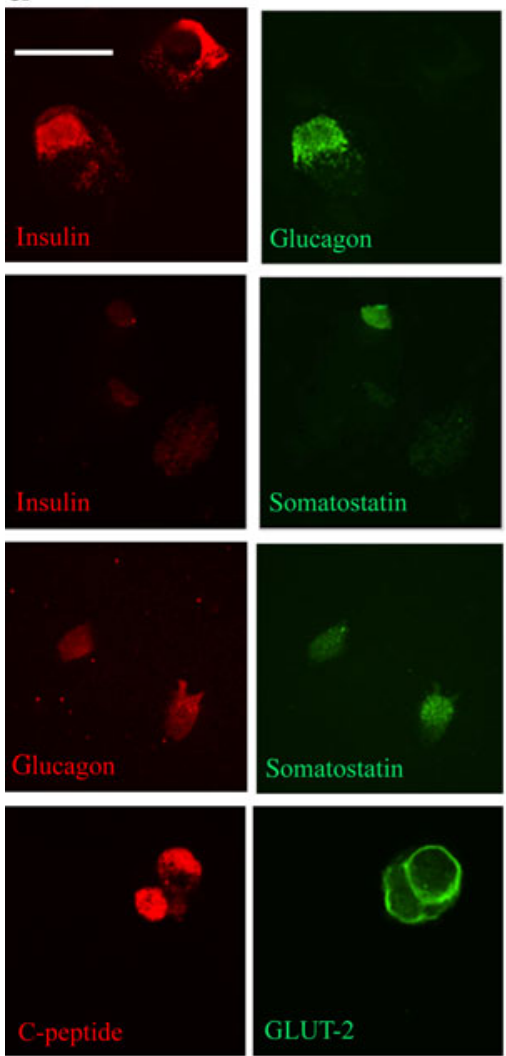

e
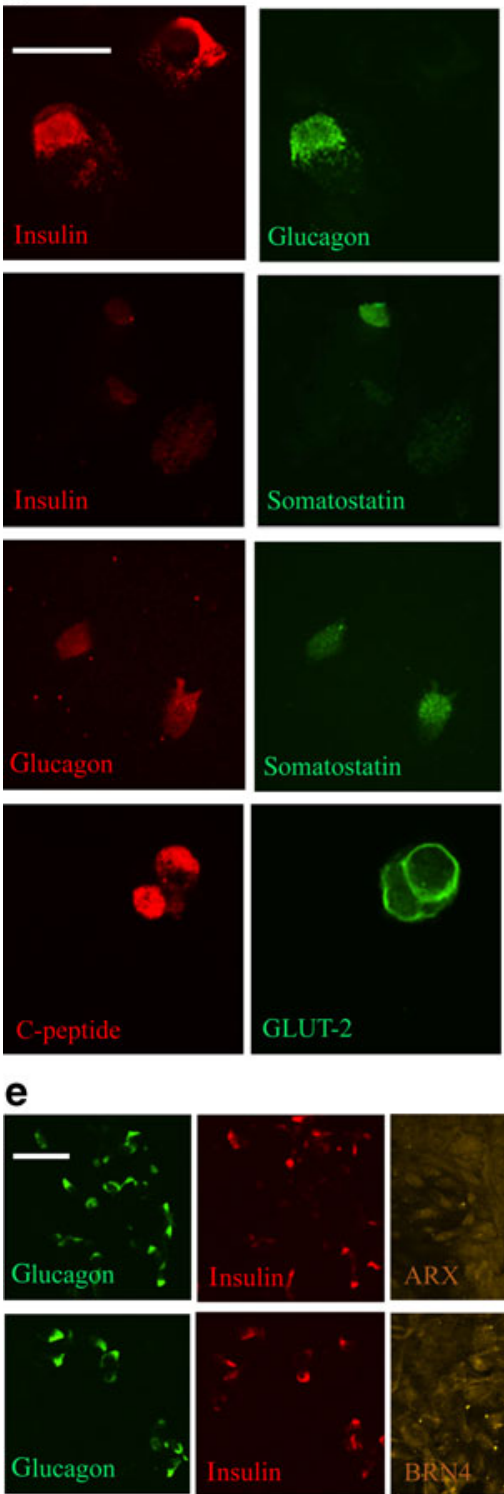

GLUT-2

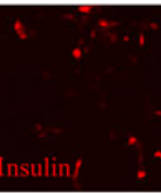

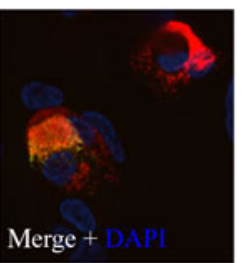
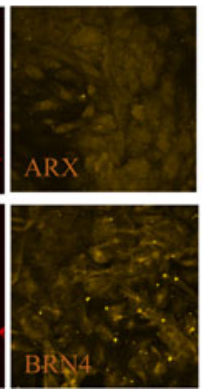
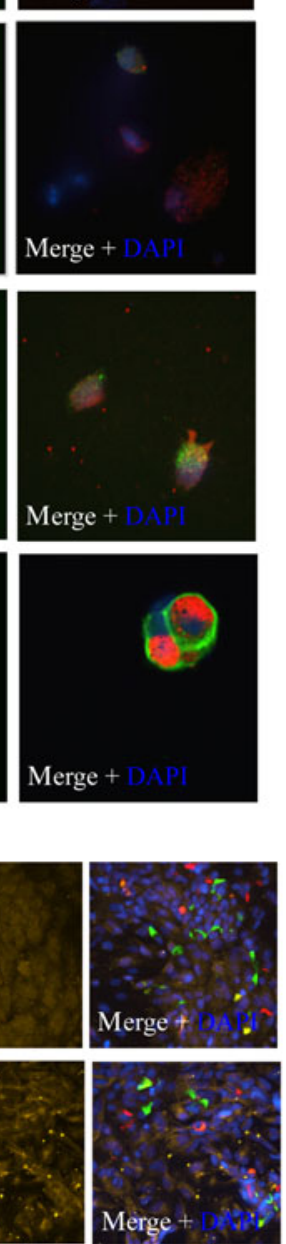

b
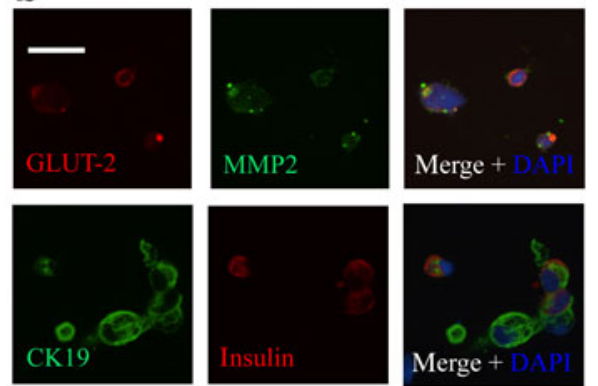

.
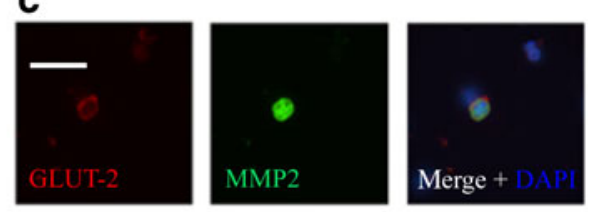

d
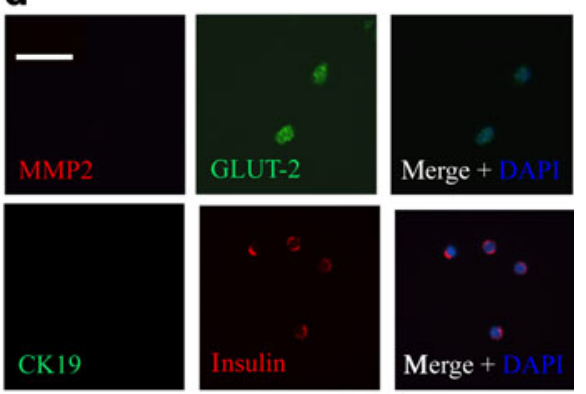

$f$
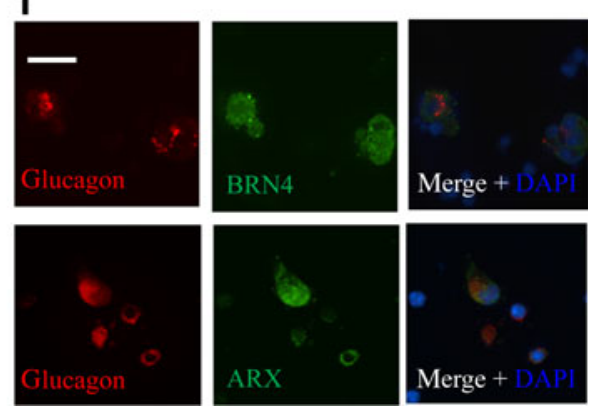

Fig. 3 d22-HES2 cells exhibit a polyhormonal phenotype and markers associated with alpha and beta cells. a Immunostaining for insulin, glucagon, somatostatin, C-peptide and GLUT2 in d22-HES2 cells. Co-localisation was examined with ImageJ software. Results were measured as an intensity correlation quotient (ICQ), where 0.5 shows a complete co-localisation value. ICQ values between insulin and glucagon were $0.387 \pm 0.01$ (mean \pm SEM), between insulin and somatostatin $0.110 \pm 0.01$, and between glucagon and somatostatin $0.173 \pm 0.004$. The trans-membrane glucose carrier protein, GLUT-
2, and C-peptide are co-produced in d22-HES2 cells. b Immunostaining for immature beta cell markers MMP2, CK19 and GLUT2 showed that d22-HES2 cells produce MMP2 (with GLUT-2) and CK19 (with insulin). c Staining as indicated in (b) in P1 murine dispersed islets and (d) in adult murine dispersed islet cells, showing that the latter no longer produce MMP2 or CK19. e Immunostaining for ARX and BRN4 in d22-HES2 cells and (f) in adult murine alpha cells. Scale bars (a-e) $50 \mu \mathrm{m}$, (f) $15 \mu \mathrm{m}$ 
lower in the INS: $\mathrm{GFP}^{+}$fraction than in human islets (ESM Fig. 7), confirming previous reports [11].

Most key ion channel genes were expressed at similar levels to those in human islets, with the exception of $A B C C 8, K C N J 11$ and KCNB1 (higher expression of all three), and $S C N 3 A$, which had significantly lower expression (ESM Fig. 6b). The expression of important metabolic and mitochondrial genes, such as $G C K, N N T$ and $A T P 5 G 3$ [17], was higher in INS: $\mathrm{GFP}^{+}$cells than in human islets (ESM Fig. 6b). Therefore, while INS:GFP ${ }^{+}$and INS:GFP cells are globally more similar to each other (Fig. 2a), the INS: $\mathrm{GFP}^{+}$population was more similar to human islets regarding genes involved in endocrine cell development and function. a

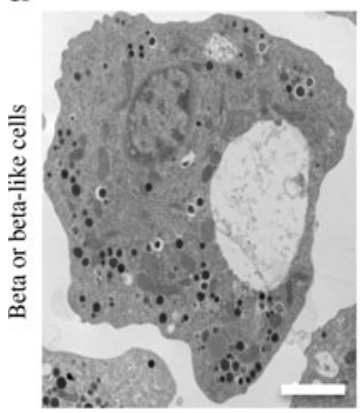

e

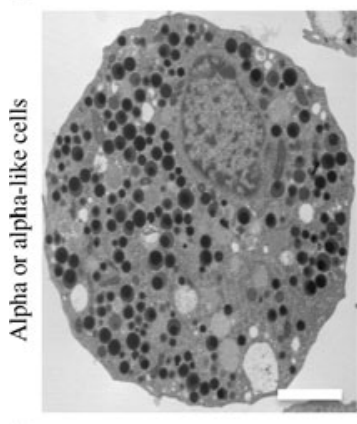

i

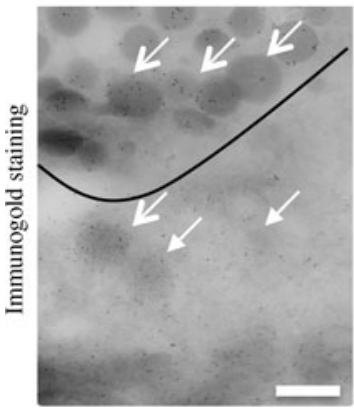

b

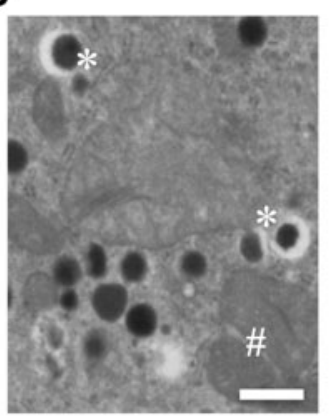

f

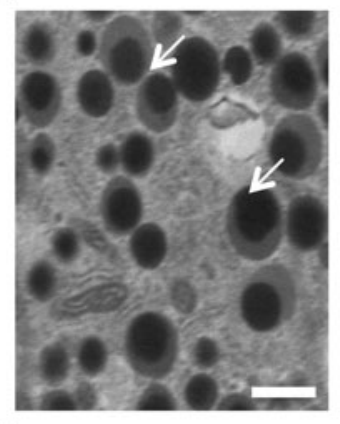

j

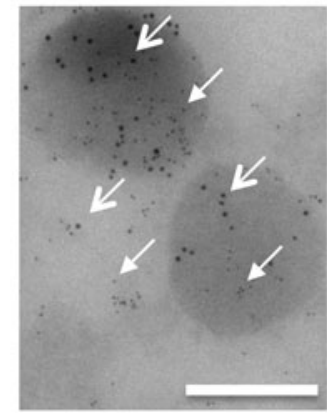

Fig. 4 Electron microscopy revealed that some d22-HES2 and purified INS:GFP ${ }^{+}$cells contain insulin granules. a The typical insulin granules can be recognised by their dense black core surrounded by a white halo. b d22-HES2 cells contained some granules with no halo and some exhibited insulin granule morphology. The cells also contain large numbers of mitochondria. a Image at low magnification, scale bar $2 \mu \mathrm{m}$, and (b) at high magnification, scale bar $500 \mathrm{~nm}$. c Murine beta cells showing normal mitochondria and insulin granules, scale bar $1 \mu \mathrm{m}$, and (d) murine beta cells at high magnification, scale bar $500 \mathrm{~nm}$. e Other d22-HES2 cells contained granules with a similar morphology, but the dense black core was surrounded by a grey halo. These cells also had fewer mitochondria than beta or alpha cells. Image is at low magnification, scale bar $2 \mu \mathrm{m}$, and (f) at high magnification, scale bar $500 \mathrm{~nm}$. g Murine alpha cell with grey

c

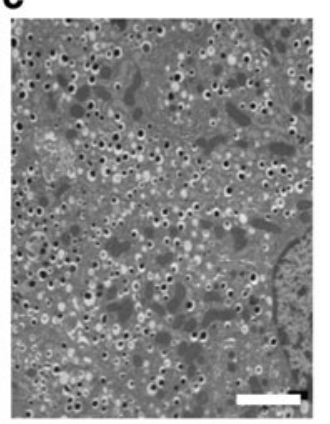

g

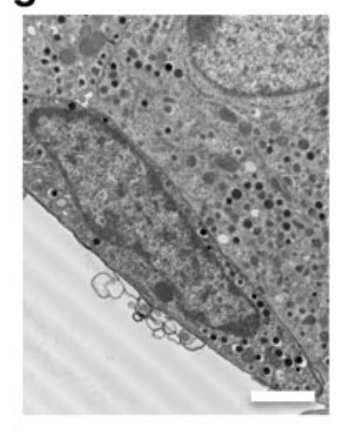

$\mathbf{k}$

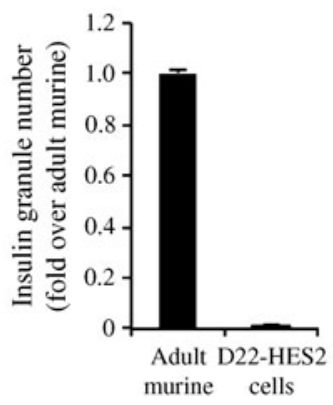

d

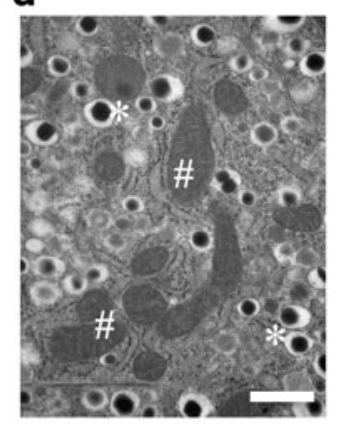

h

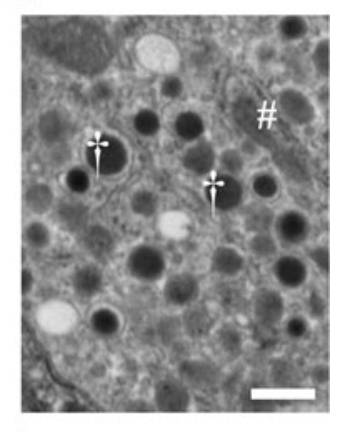

I

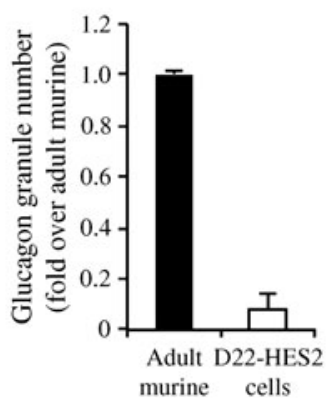

glucagon granules. There are no examples of the grey halo granule morphology. Scale bar $1 \mu \mathrm{m}$. h Murine alpha cell at high magnification, scale bar $500 \mathrm{~nm}$. a-h Asterisks (*), dense core (insulin) granules; arrows, grey halo granules; dagger symbols $(\dagger)$, glucagon granules; hash symbols (\#), mitochondria. i Immunogold labelling revealed that some INS: $\mathrm{GFP}^{+}$cells produce only insulin (10 $\mathrm{nm}$ gold particles, open head arrows), while some produce insulin and glucagon (6 nm particles, closed head arrows), scale bar $500 \mathrm{~nm}$. j In bi-hormonal INS:GFP ${ }^{+}$cells insulin (open head arrows) and glucagon (closed head arrows) are also found in the cytoplasm, scale bar $500 \mathrm{~nm}$. k, I The granule number was much lower in d22-HES2 cells than in murine islet cells; there were 100 times fewer typical insulin granules (k) and 12.5 times fewer typical glucagon granules (l) 
Immunofluorescent staining

To determine hormone production and cell maturity, we used immunofluorescent staining. Insulin and GFP were completely co-localised in purified INS:GFP ${ }^{+}$cells (Fig. 1b). However, d22-HES2 insulin ${ }^{+}$cells were often polyhormonal (Fig. 3a). In a heterogeneous population of d22-HES2 cells, $19.77 \pm 13.80 \%$ (mean \pm SEM) were insulin $^{+}, 9.3 \pm 1.06 \%$ were glucagon ${ }^{+}$and $7.7 \pm 0.4 \%$ were somatostatin $^{+}$( $n=3$ batches of cells, 480 cells total). Cells also co-produced C-peptide and GLUT-2 (Fig. 3a).

To assess the degree of $\mathrm{d} 22$-HES2 cell maturity, we examined the presence of the immature beta cell markers matrix metallopeptidase 2 (gelatinase A, $72 \mathrm{kDa}$ gelatinase or type IV collagenase) (MMP2), a neutral endopeptidase that cleaves most extracellular matrix proteins and is important in islet formation [32, 33], and cytokeratin 19 (CK19), an intermediate filament protein that is found in the basal epidermis and is indicative of cells in a flexible state of differentiation [33]. MMP2 and CK19 were present in d22-HES2 cells (Fig. 3b) and in murine islets at postnatal day 1 (P1) (Fig. 3c), but not in adult murine beta cells (Fig. 3d), suggesting that d22-HES2 cells have an immature endocrine phenotype [33]. The alpha cell-specific transcription factors, aristaless related homeobox (ARX) and brainspecific homeobox/POU domain protein 4 (BRN4), colocalised with insulin ${ }^{-} /$glucagon $^{+}$, insulin $^{+} /$glucagon $^{-}$and insulin $^{+} /$glucagon $^{+} \mathrm{d} 22$-HES2 cells (Fig. 3e), and also colocalised with glucagon in adult murine alpha cells (Fig. 3f) $(n=3)$.

\section{Electron microscopy}

For beta cells to secrete insulin, they must synthesise and package it correctly in secretory granules. The cellular ultrastructure of d22-HES2 cells was examined by electron microscopy and compared with that of murine beta cells. Insulin granules are characterised by a dense black core surrounded by a white halo [34] when fixed using aldehyde [35] (Fig. 4c, d). d22-HES2 cells had fewer total granules than murine beta cells (Fig. $4 \mathrm{a}, \mathrm{c}, \mathrm{k}$ ), and only about $2 \%$ of cells contained 'typical' insulin granules. Of the cells containing insulin-like granules, only around $12 \%$ of all granules displayed the typical morphology; the others were more reminiscent of a glucagon granule, containing a dense black or grey core without a halo [30] (Fig. 4a, b). Another $2 \%$ of all $\mathrm{d} 22$-HES 2 cells contained unusual granules with a dense black core surrounded by a grey halo (18\% of all granules in this cell type) (Fig. 4e, f). The remaining 96\% of $\mathrm{d} 22$-HES2 cells contained only granules without a halo which are more like murine alpha cell granules (Fig. 4g, h). The granule number was much lower in $\mathrm{d} 22$-HES2 cells than in murine beta cells, with 100-times fewer insulin-like granules (Fig. 4k) and 12.5-times fewer glucagon-like granules (Fig. 4l) in the former. Consistent with an islet cell phenotype, and due to their role in glucose metabolism, all cells with typical insulin granules had many mitochondria (Fig. 4b, d, h).

Immunogold labelling of purified INS:GFP ${ }^{+}$cells revealed that $24.5 \pm 10 \%$ of granules were insulin ${ }^{+}, 33.0 \pm$ $11 \%$ glucagon $^{+}$and $35.0 \pm 12 \%$ insulin- and glucagonpositive, while $7.5 \pm 1 \%$ contained neither insulin nor glucagon (Fig. 4i). Cytosolic hormone production was also observed, with $10 \pm 10 \%$ containing cytosolic insulin, $20 \pm$ $13 \%$ glucagon and $50 \pm 17 \%$ both $(n=3)$ (Fig. $4 \mathrm{j}$ ).

\section{Hormone secretion}

The hallmark of a mature beta cell is its ability to secrete insulin in response to high glucose, so it was very important to determine the glucose responsiveness of $\mathrm{d} 22$-HES2 cells. In all cases, human and murine islets secreted insulin in response to high glucose and direct cellular depolarisation $(30 \mathrm{mmol} /$ $1 \mathrm{KCl}$ ) (Fig. 5a, b and ESM Tables 3 and 4). However, d22HES2 cells only secreted insulin consistently under direct cellular depolarisation and did not respond to glucose (Fig. 5c and ESM Table 5). During this depolarisationinduced secretion, d22-HES2 cells secreted approximately 1.5-fold less insulin than human islets, i.e. $3.541( \pm 1.40)$ and $5.16 \pm 0.82 \mathrm{ng} / \mu \mathrm{g}$ DNA respectively. However, this was not significant (ESM Tables 3 and 5). Moreover, d22-HES2 cells contained approximately five-fold less total insulin than human islets, i.e.: $496.79 \pm 0.04$ vs $2,221.0 \pm 904.35 \mathrm{ng}$ insulin $/ \mu \mathrm{g}$ DNA, respectively $(p<0.05)$.

In contrast to insulin secretion, d22-HES2 cells secreted glucagon in response to direct depolarisation $(30 \mathrm{mmol} /$ $1 \mathrm{KCl}$ ) and half the time also responded to low glucose (Fig. 5f and ESM Table 5) similarly to human and murine islets (Fig. 5d, e and ESM Tables 3 and 4). The d22-HES2 cells secreted approximately 4.4-fold less glucagon than human islets, i.e. $28.74 \pm 17.89$ versus $123.17 \pm 19.41 \mathrm{pg} / \mu \mathrm{g}$ DNA, respectively $(p<0.05)$ (ESM Tables 3 and 5). Total glucagon content was approximately 146 -fold lower in d22HES2 cells than in human islets, i.e. $172.56 \pm 32.92$ vs $25,218.41 \pm 7,527.25 \mathrm{pg} / \mu \mathrm{g}$ DNA, respectively $(n=3, p<$ 0.05). Collectively, this supports the observation by transmission electron microscopy that INS:GFP ${ }^{+}$cells had fewer granules.

$\mathrm{Ca}^{2+}$ uptake

To provide a more in-depth mechanism linking glucose metabolism to insulin secretion, cytosolic $\mathrm{Ca}^{2+}$ flux, which mirrors cellular electrical activity and biphasic insulin secretion [12], was measured. In $81 \%$ of purified INS: $\mathrm{GFP}^{+}$cells we observed increased levels of intracellular 

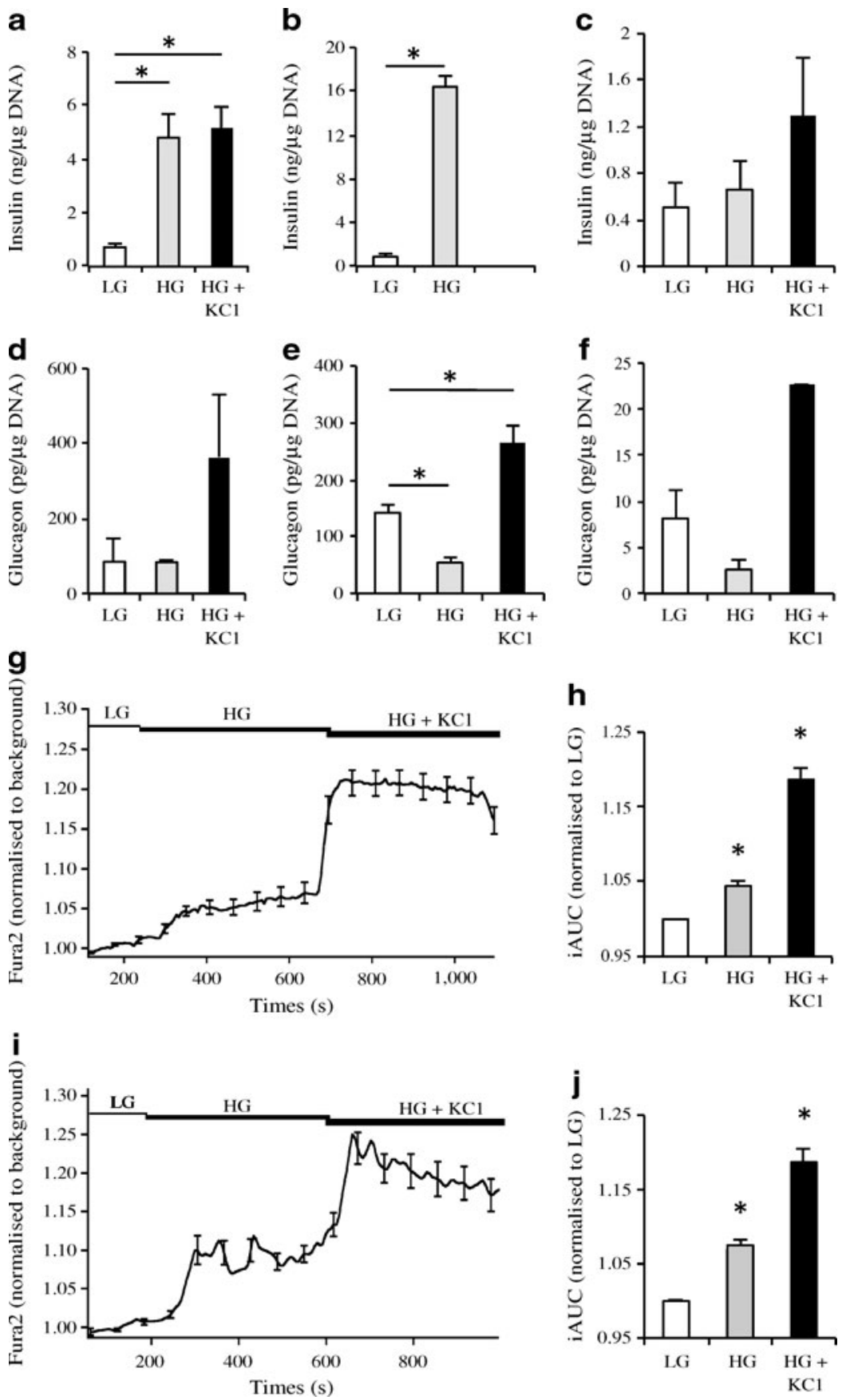

Fig. 5 Insulin $^{+}$hESCs do not secrete hormones in response to high glucose but do increase their intracellular calcium levels half of the time. a Representative insulin secretion from human islets, (b) murine islets and (c) d22-HES2 cells. d-f Representative glucagon secretion from the same cell groups. a In all experiments human islets secreted insulin in response to high glucose (HG: $20 \mathrm{mmol} / \mathrm{l}$ ) (grey bars) and glucose plus direct depolarisation $(\mathrm{HG}+\mathrm{KCl}: 30 \mathrm{mmol} / \mathrm{KCl})$ (black bars). White bars, low glucose (LG: $1 \mathrm{mmol} / \mathrm{l}$ ). b Murine islets secreted insulin in response to HG. c All d22-HES2 cells secreted insulin due to $\mathrm{HG}+\mathrm{KCl}$, but did not respond to $\mathrm{HG}$. d Human islets secreted glucagon in response to $\mathrm{HG}+\mathrm{KCl}$. e Murine islets secreted glucagon in response to $\mathrm{LG}$ and $\mathrm{HG}+\mathrm{KCl}$, and (f) d22-HES2 cells secreted glucagon in all experiments due to $\mathrm{HG}+\mathrm{KCl}$. In five batches (f) cells were also responsive to LG. a-f Hormone secretion was normalised to total DNA content. Raw data can be found in ESM Tables 3-5. Representative results are shown; $n=11 .{ }^{*} p<0.05$. $\mathbf{g}$, h Cytosolic $\mathrm{Ca}^{2+}$ flux in INS:GFP ${ }^{+}$cells and (i, j) human islet cells in response to $\mathrm{HG}$ and $\mathrm{HG}+\mathrm{KCl}$. g Average of responses from all INS:GFP ${ }^{+}$cells, with (h) the average incremental AUC (iAUC) for all cells, normalised to the LG values; $n=42$, in three cell batches. i Average of responses from all dispersed human islet cells, with (j) bar graph showing the average incremental AUC for all cells, normalised to the LG values; $n=45$, cells from three cell batches. Horizontal bars $(\mathrm{g}, \mathbf{i})$ represent perifusion with the corresponding reagents; error bars represent $\pm \mathrm{SEM} ;{ }^{*} p<0.05$ 
$\mathrm{Ca}^{2+}$ during cellular depolarisation $(30 \mathrm{mmol} / \mathrm{KCl})$; these increases were similar to those in human islet cells (Fig. $5 \mathrm{~g}-\mathrm{j}$ ). Interestingly, $57 \%$ of INS:GFP ${ }^{+}$cells responded to high glucose (significant difference in the incremental AUC) (ESM Fig. 8), indicating that a subset of INS:GFP ${ }^{+}$cells were able to increase cytosolic $\mathrm{Ca}^{2+}$ similarly to human islet cells (Fig. $5 \mathrm{~g}, \mathrm{~h}$ ); however, this did not translate into glucoseinduced insulin secretion $(n=3)$.

\section{Electrophysiology}

Since hormone secretion and $\mathrm{Ca}^{2+}$ uptake are dependent on ion channel activity, we examined the electrogenic response. Following $\mathrm{K}_{\text {ATP }}$ channel closure and cellular depolarisation, L-type $\mathrm{Ca}^{2+}$ channels open allowing $\mathrm{Ca}^{2+}$ entry and insulin exocytosis, before activation of $\mathrm{K}_{\mathrm{V}}$ channels repolarise the cell to its resting state [36].

Whole-cell recordings revealed $\mathrm{K}_{\mathrm{ATP}}$ currents in human islet cells. However, such currents were not consistently observed in INS: $\mathrm{GFP}^{+}$cells. Individual cell traces are shown in ESM Fig 1a. The $\mathrm{K}_{\mathrm{ATP}}$ channel activator diazoxide $(100 \mu \mathrm{mol} / \mathrm{l})$ activated a $\mathrm{K}_{\mathrm{ATP}}$ current in human islet cells (Fig. 6b) and murine beta cells (ESM Fig. 4a) that was blocked by application of the $\mathrm{K}_{\mathrm{ATP}}$ channel-specific blocker, tolbutamide. A similar response was observed in five of $11(45.5 \%)$ INS: $\mathrm{GFP}^{+}$cells (Fig. 6a), whereas the remaining six did not respond (ESM Fig. 3). Whole-cell $\mathrm{K}_{\text {ATP }}$ current recordings were also collected in P1 murine beta cells (ESM Fig. 2b) as a control and showed that blockage occurred upon tolbutamide application.

Whole-cell recordings showed $\mathrm{K}_{\mathrm{V}}$ currents in all INS: $\mathrm{GFP}^{+}$cells; these currents were substantially reduced by the delayed rectifier $\mathrm{K}_{\mathrm{V}}$ current blocker, tetra-ethyl ammonium (TEA, $20 \mathrm{mmol} / \mathrm{l}$; Fig. 6c). Individual cell traces are shown in ESM Fig. $1 b$. Control $\mathrm{K}_{\mathrm{V}}$ recordings were also collected in dispersed human islet cells (Fig. 6d), and in P1 and murine beta cells (ESM Figs $2 \mathrm{a}$ and $4 \mathrm{~d}$ ) with similar TEA inhibition.

Whole-cell $\mathrm{Ca}^{2+}$ current recordings were examined in human islet cells and INS:GFP ${ }^{+}$cells with a ramp stimulation protocol applied at $0.47 \mathrm{mV} / \mathrm{ms}$ to prevent activation of voltage-gated $\mathrm{Na}^{+}$channels. Nifedipine (Ltype $\mathrm{Ca}_{\mathrm{V}}$ channel blocker) decreased the $\mathrm{Ca}^{2+}$ current in human islet cells (Fig. 6f), whereas the INS:GFP ${ }^{+}$cells displayed a nifedipine-resistant $\mathrm{Ca}^{2+}$ current in six of 14 cells $(42 \%)$ (Fig. 6e).

When human islet cells (Fig. 6i-j) and murine beta cells (ESM Fig. 4c) were held at a potential of $-120 \mathrm{mV}$ and stimulated with a protocol similar to the one used to record $\mathrm{K}$, a fast inward $\mathrm{Na}^{+}$current was detected. The same protocol used on INS:GFP ${ }^{+}$cells did not show any voltage gated $\mathrm{Na}^{+}$current $(n=3)$ (Fig. $\left.6 \mathrm{~g}-\mathrm{h}\right)$.
Developmental potential

To evaluate the developmental potential of INS: $\mathrm{GFP}^{+}$cells, FACS-sorted cells were transplanted into the mammary fat pad of NOD-SCID- $\gamma$ mice $(n=3)$. Graft analysis 1 month post transplant revealed a homogeneous population of glucagon-positive, insulin-negative cells. For more details, see ESM text and ESM Fig. 9.

\section{Discussion}

The 'Nostro protocol' [11] consistently generated insulin ${ }^{+}$ cells in vitro from the $I N S^{G F P / w}$ reporter line and a HES2 line. The use of hESC-derived INS: $\mathrm{GFP}^{+}$cells enabled us to correlate the results of gene expression with electrophysiological and ultrastructural studies of purified insulin ${ }^{+}$ cells. End-stage cells were often polyhormonal, with presence of markers such as MMP2 and CK19, which are characteristic of immature pancreatic cells. Immunogold staining of INS: $\mathrm{GFP}^{+}$cells confirmed the presence of defined insulin [18] and glucagon granules [30], many bi-hormonal granules, and some cytosolic insulin and glucagon. INS: $\mathrm{GFP}^{+}$cells exhibited $\mathrm{K}_{\mathrm{ATP}}$ and nifedipineresistant $\mathrm{Ca}_{\mathrm{V}}$ currents half the time, and lacked $\mathrm{Na}^{+}$ currents. Critically, we showed key molecular and functional differences between hESC-derived insulin ${ }^{+}$cells and human beta cells, despite many striking similarities.

Glucose-regulated insulin secretion, the hallmark of a mature beta cell, still eludes us, as the hESC-derived insulin $^{+}$cells generated in vitro only secreted insulin following membrane depolarisation. The amount of secreted and intracellular insulin was 1.5 - to 5 -fold lower in the current iteration of differentiated hESCs than in human islets per $\mu \mathrm{g}$ DNA. However, if the relative ratios of insulin ${ }^{+}$cells in the d22-HES2 cultures $(\sim 20 \%)$ and in human islets $(\sim 80 \%)$ are considered, then the insulin ${ }^{+}$cells actually secrete similar amounts of insulin per cell under membrane depolarisation. The lack of glucose-responsive insulin release suggests that the INS: $\mathrm{GFP}^{+}$cells have a deficiency in glucose-sensing, metabolism, insulin processing and/or exocytosis. Molecular analysis showed no difference in GLUT-1, the primary transporter of glucose into human beta cells [37]. The key glycolytic gene $G C K$ and numerous genes involved in mitochondrial metabolism of glucose and generation of ATP, such as NNT and ATP synthase subunits, were more highly expressed in INS:GFP ${ }^{+}$cells than in human islets, suggesting that there are no obvious metabolic deficiencies (ESM Fig. 10b). Collectively, this implies that INS: $\mathrm{GFP}^{+}$cells have sufficient expression of genes involved in glucose-sensing and metabolism, but are still in an immature, polyhormonal state that limits their glucose responsiveness. 
a

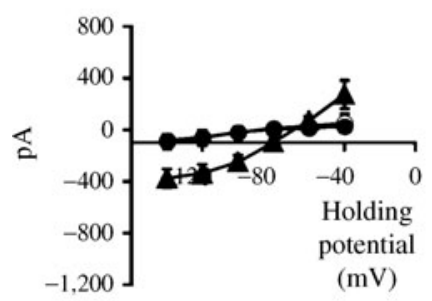

e

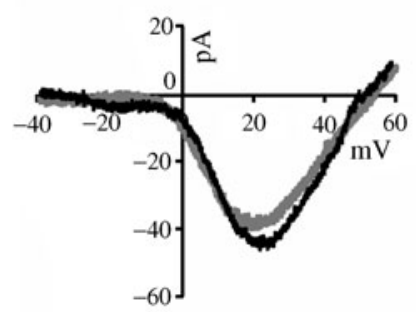

b

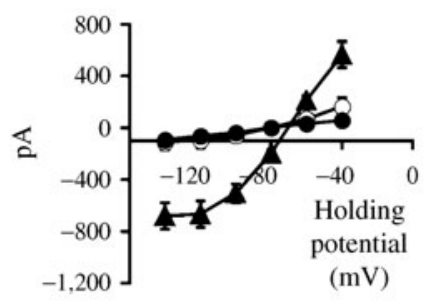

f

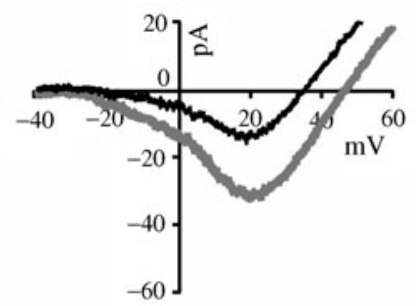

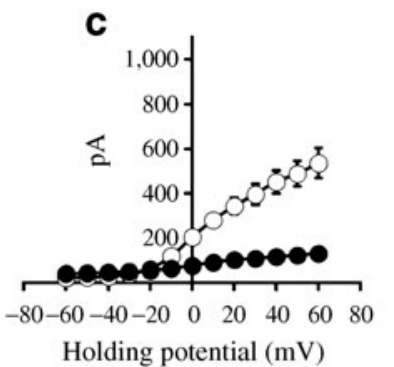

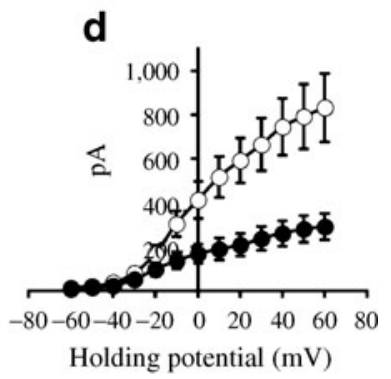

g

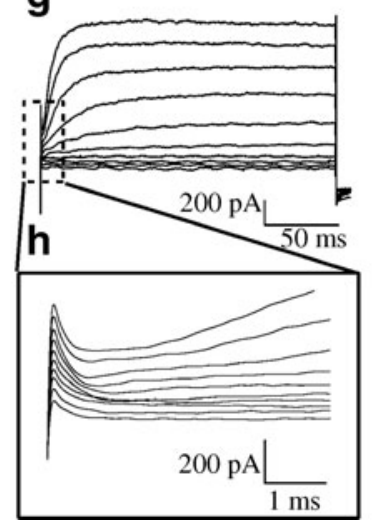

i

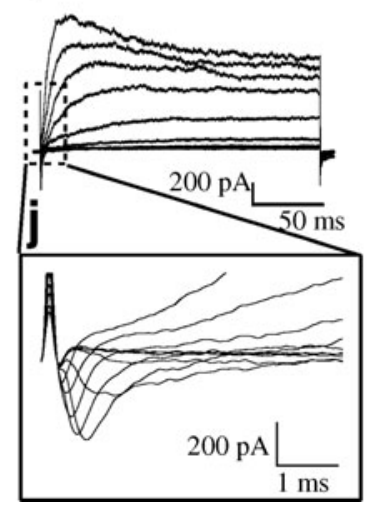

Fig. 6 Whole cell recordings of $\mathrm{K}_{\mathrm{ATP}}, \mathrm{Ca}_{\mathrm{V}}, \mathrm{Na}^{+}$and $\mathrm{K}_{\mathrm{V}}$ currents in dispersed INS:GFP cells and human islet cells. Average $I / V$ curves in (a) INS:GFP ${ }^{+}$cells and (b) human islet cells were obtained by measuring the maximum current and plotting these against the applied potential ( $n=5$ for each). Black circles, tolbutamide; triangles, diazoxide; white circles, $\mathrm{K}_{\mathrm{ATP}}$ current recordings at rest (control). In human islet cells $(\mathbf{b})$, diazoxide $(100 \mu \mathrm{mol} / \mathrm{l})$ application produced a large $\mathrm{K}_{\text {ATP }}$ current that was blocked by tolbutamide $(250 \mu \mathrm{mol} / 1) . \mathrm{K}_{\mathrm{V}}$ current recordings in (c) INS: $\mathrm{GFP}^{+}$cells $(n=3)$, and (d) human islet cells $(n=7)$. Average $I / V$ curves were obtained by measuring the maximum current and plotting these against the applied potential.

Ion channels link beta cell glucose sensing to insulin secretion. D'Amour et al. observed glucose-responsive Cpeptide release from hESC-derived endocrine cells only $10 \%$ of the time. They confirmed the presence of the $\mathrm{K}_{\mathrm{ATP}}$ channel genes $A B C C 8$ and $K C N J 11$ by PCR, but did not perform electrophysiological analysis [8]. Our studies show that despite $\mathrm{K}_{\text {ATP }}$ channels being more highly expressed in INS: $\mathrm{GFP}^{+}$cells than in human islets, the channels were active only $45 \%$ of the time. In addition, glucose-mediated $\mathrm{Ca}^{2+}$ uptake, which is distal to the $\mathrm{K}_{\text {ATP }}$ channel and required for insulin exocytosis [25], was measured in only $57 \%$ of INS: $\mathrm{GFP}^{+}$cells, with $42 \%$ displaying a nifedipineresistant voltage-dependent $\mathrm{Ca}^{2+}$ current. Collectively, the heterogeneous channel activity supports the lack of glucosemediated insulin secretion and could be explained by two different scenarios. First, there may be a discrepancy between mRNA expression and protein levels. Second, channels are translated but may not be functional in polyhormonal cells. Previous studies have demonstrated that embryonic and postnatal rodent beta cells are polyhormonal and also poorly
White circles, control; black circles, TEA. Representative $\mathrm{Ca}_{\mathrm{V}}$ current recordings in (e) INS: $\mathrm{GFP}^{+}$cells and (f) human islet cells in response to a voltage ramp. In six of $14 \mathrm{INS}: \mathrm{GFP}^{+}$cells a $\mathrm{Ca}_{\mathrm{V}}$ current was present (control, grey line), but not blocked by nifedipine $(10 \mu \mathrm{mol} / \mathrm{l})$ (black line), whereas in human islet cells (f) nifedipine decreased the $\mathrm{Ca}_{\mathrm{V}}$ current $(n=6)$. Representative whole cell current recordings of $\mathrm{Na}^{+}$current in $(\mathbf{g}, \mathbf{h})$ INS:GFP ${ }^{+}$cells and $(\mathbf{i}, \mathbf{j})$ in human islet cells. The early time scale (dashed line boxes in $\mathbf{g}$ and $\mathbf{i}$ ) was enlarged and is shown separately. g, h INS: $\mathrm{GFP}^{+}$cells held at $-120 \mathrm{mV}$ did not show any voltage-gated $\mathrm{Na}^{+}$current $(n=7)$. $\mathbf{i}$, $\mathbf{j}$ Dispersed human islet cells held at $-120 \mathrm{mV}$ displayed a voltage-gated $\mathrm{Na}^{+}$current $(n=6)$

responsive to glucose, in part due to reduced levels of key stimulus-secretion coupling proteins, including glucose transporters and $\mathrm{Ca}_{\mathrm{V}}$ channels; they also lack $\mathrm{K}_{\mathrm{ATP}}$ channel activity [38-40]. Although we are unable to compare INS:GFP ${ }^{+}$cells with human embryonic beta cells, the above suggests that most hESC-derived insulin ${ }^{+}$cells resemble immature endocrine cells, but the subset showing normal channel activity might represent more mature endocrine cells.

Activation of a $\mathrm{K}_{\mathrm{V}}$ current is required for the regulation of insulin and glucagon secretion [41, 42]. We found that $\mathrm{K}_{\mathrm{V}}$ channels were functionally present in all INS:GFP ${ }^{+}$cells. In addition, $K C N B 1$ expression was significantly higher in INS: $\mathrm{GFP}^{+}$cells than in human islets as measured by microarray. It is possible that $\mathrm{K}_{\mathrm{V}}$ channel over-activity in INS: $\mathrm{GFP}^{+}$cells could hyperpolarise the plasma membrane and limit insulin secretion, especially when glucose is present. Future studies should test this theory, but currently the electrophysiological data suggests that our cells more closely resemble naive endocrine cells than hyperpolarised ones. 
While INS:GFP ${ }^{+}$and INS:GFP ${ }^{-}$cells express endodermal markers, INS: $\mathrm{GFP}^{-}$cells show increased expression of non-pancreatic foregut-derivative and neuronal markers (data not shown), suggesting that this fraction is very heterogeneous. Stronger hormone expression in INS:GFP ${ }^{+}$ cells indicates that they are more endocrine-committed (we predict past murine embryonic day 10.5 or human week 4 [ESM Fig. 10a]). Upregulation of transcription factors required for endocrine specification in INS: $\mathrm{GFP}^{+}$cells compared with human islets occurred for those expressed following NGN3-dependent endocrine commitment and included ISL1, NEUROD1, PAX6 and PROX1. Cells at this stage are often labelled cells of the 'first' transition of pancreatic development, which in the mouse embryo do not produce mature beta cells [24]. Instead, cells from the 'second' transition of pancreatic development, a welldefined group of hormone ${ }^{+}$cells that delaminate from the pancreatic epithelium, are thought to mature into islet cells $[43,44]$. This, together with our observation that most, but not all INS: $\mathrm{GFP}^{+}$cells are polyhormonal and co-express $G C G$ and/or SST suggests they may be misdifferentiated and unable to generate mature beta cells. However, we also observed upregulation of some alpha $(A R X, I R X 1 / 2)$ [30, 31] and beta (MAF and INSM1) [40, 45] cell lineagespecific transcription factors, suggesting that a small proportion of cells might be heading towards a mature endocrine cell phenotype.

High levels of alpha cell-specific transcription factors, glucose-responsive glucagon secretion and transplantation results where the INS: $\mathrm{GFP}^{+}$cells downregulated insulin expression and expressed only glucagon (ESM Fig. 9) raise the possibility that some insulin ${ }^{+}$cells could be becoming functional alpha cells, as was observed by Rezania et al. using H1-derived pancreatic-differentiated cultures [30]. A recent study by Kelly et al. showed that cells transplanted after sorting using a 'pancreatic endoderm' surface marker antibody were able to generate monohormonal INS-, GCG-, and SST-expressing cells. However, cells sorted using an 'endocrine-like' surface marker antibody, and thus hormone-positive cells, generated only glucagon-producing cells in vivo [46]. Our transplant data, which support these findings that hormone-positive cells become homogeneously glucagon-positive in vivo, raises the possibility that unknown in vivo factor(s) are required to convert pancreatic endodermal cells to beta cells and that this factor is missing in current in vitro protocols. It is also possible that monohormonal insulin ${ }^{+}$cells may not survive in vivo and that polyhormonal cells residing in the INS: $\mathrm{GFP}^{+}$fraction survive and differentiate into alpha cells [47]. However, given the right differentiation conditions [47] or genetic manipulation, it may be possible to increase the percentage of monohormonal hESC-derived insulin ${ }^{+}$cells and improve glucose responsiveness.
NKX6-1 is required for beta cell specification and glucose-mediated insulin secretion [48, 49], and its overproduction promotes INS expression while simultaneously suppressing $G C G$ expression [50]. Based on the success of a recent study showing that glucose responsiveness could be induced in postnatal day 2 rat islet cells by transduction of $M A F$ expression [40], we speculate that the addition of key transcription factors such as NKX6-1 could improve the generation of functional insulin ${ }^{+}$cells from hESCs. Therefore, future studies will use the genetic profiling and functional data gained in this study to identify potential targets for molecular manipulation during differentiation. This strategy may allow us to produce fully functional pancreatic beta cells in vitro from $\mathrm{hESC}$.

Acknowledgements We would like to thank A.M.J. Shapiro and T. Kin at the Clinical Islet Laboratory, University of Alberta (Edmonton $\mathrm{AB}$, Canada) for the human islets used in this study. We would also like to thank R. Wang for helpful discussions and the gift of MMP2 and CK19 antibodies. We would also like to thank K. Seergobin at the Centre for Biological Timing and Cognition, University of Toronto, ON, Canada for his help and expertise in confocal microscopy, and J. Stewart at the Ontario Cancer Institute, Toronto for assistance with the transplantations. This work was supported by a grant from CIHR MOP-111241 to M.B. Wheeler. C.L. Basford was supported by a BBDC postdoctoral fellowship. K.J. Prentice was supported by a BBDC-University Health Network graduate award. M.C. Nostro was supported by a Postdoctoral Fellowship from the McEwen Centre for Regenerative Medicine. S.J. Micallef, X. Li, A.G. Elefanty and E.G. Stanley are supported by the Australian Stem Cell Centre (ASCC), The National Health and Medical Research Council (NHMRC) of Australia and The Juvenile Diabetes Research Foundation.

Contribution statement CLB researched the data and wrote the manuscript. KJP, $\mathrm{ABH}$ and EMA researched the data and reviewed/edited the manuscript. QG researched the data and contributed to the manuscript. MCN designed the differentiation protocols, contributed the hESC and reviewed/edited the manuscript. FS contributed the hESC, researched the data and contributed to the manuscript. SJM, $\mathrm{XL}, \mathrm{AGE}$ and EGS designed and developed the $I N S^{G F P / w} \mathrm{hESC}$ and reviewed/edited the manuscript. GK designed the differentiation protocols, contributed the hESC and reviewed/edited the manuscript. MBW designed the study and contributed to the writing of the manuscript. All authors approved the final version to be published.

Duality of interest The authors declare that there is no duality of interest associated with this manuscript.

\section{References}

1. Shapiro AM, Lakey JR, Ryan EA et al (2000) Islet transplantation in seven patients with type 1 diabetes mellitus using a glucocorticoid-free immunosuppressive regimen. N Engl J Med 343:230-238

2. Correa-Giannella ML, Raposo do Amaral AS (2009) Pancreatic islet transplantation. Diabetol Metab Syndr 1:9

3. Chen S, Borowiak M, Fox JL et al (2009) A small molecule that directs differentiation of human ESCs into the pancreatic lineage. Nat Chem Biol 5:258-265 
4. Jiang J, Au M, Lu K et al (2007) Generation of insulin-producing islet-like clusters from human embryonic stem cells. Stem Cells 25:1940-1953

5. Jiang W, Shi Y, Zhao D et al (2007) In vitro derivation of functional insulin-producing cells from human embryonic stem cells. Cell Res 17:333-344

6. Mfopou JK, Chen B, Mateizel I, Sermon K, Bouwens L (2010) Noggin, retinoids, and fibroblast growth factor regulate hepatic or pancreatic fate of human embryonic stem cells. Gastroenterology 138:2233-2245

7. Zhang D, Jiang W, Shi Y, Deng H (2009) Generation of pancreatic islet cells from human embryonic stem cells. Sci China C Life Sci 52:615-621

8. D'Amour KA, Bang AG, Eliazer S et al (2006) Production of pancreatic hormone-expressing endocrine cells from human embryonic stem cells. Nat Biotechnol 24:1392-1401

9. Kroon E, Martinson LA, Kadoya K et al (2008) Pancreatic endoderm derived from human embryonic stem cells generates glucose-responsive insulin-secreting cells in vivo. Nat Biotechnol 26:443-452

10. Matveyenko AV, Georgia S, Bhushan A, Butler PC (2010) Inconsistent formation and nonfunction of insulin-positive cells from pancreatic endoderm derived from human embryonic stem cells in athymic nude rats. Am J Physiol Endocrinol Metab 299: E713-E720

11. Nostro MC, Sarangi F, Ogawa S et al (2011) Stage-specific signaling through TGFbeta family members and WNT regulates patterning and pancreatic specification of human pluripotent stem cells. Development 138:861-871

12. Hardy AB, Fox JE, Giglou PR et al (2009) Characterization of Erg $\mathrm{K}^{+}$channels in alpha- and beta-cells of mouse and human islets. J Biol Chem 284:30441-30452

13. Smukler SR, Arntfield ME, Razavi R et al (2011) The adult mouse and human pancreas contain rare multipotent stem cells that express insulin. Cell Stem Cell 8:281-293

14. Diao J, Allister EM, Koshkin V et al (2008) UCP2 is highly expressed in pancreatic alpha-cells and influences secretion and survival. Proc Natl Acad Sci USA 105:12057-12062

15. Lyttle BM, Li J, Krishnamurthy M et al (2008) Transcription factor expression in the developing human fetal endocrine pancreas. Diabetologia 51:1169-1180

16. Nicolson TJ, Bellomo EA, Wijesekara $N$ et al (2009) Insulin storage and glucose homeostasis in mice null for the granule zinc transporter ZnT8 and studies of the type 2 diabetes-associated variants. Diabetes 58:2070-2083

17. Lu H, Koshkin V, Allister EM, Gyulkhandanyan AV, Wheeler MB (2010) Molecular and metabolic evidence for mitochondrial defects associated with beta-cell dysfunction in a mouse model of type 2 diabetes. Diabetes 59:448-459

18. Wijesekara N, Dai FF, Hardy AB et al (2010) Beta cell-specific Znt8 deletion in mice causes marked defects in insulin processing, crystallisation and secretion. Diabetologia 53:1656-1668

19. Tam P, Mahfoud R, Nutikka A et al (2008) Differential intracellular transport and binding of verotoxin 1 and verotoxin 2 to globotriaosylceramide-containing lipid assemblies. J Cell Physiol 216:750-763

20. Leung YM, Ahmed I, Sheu L et al (2005) Electrophysiological characterization of pancreatic islet cells in the mouse insulin promoter-green fluorescent protein mouse. Endocrinology $146: 4766-4775$

21. Bonal C, Herrera PL (2008) Genes controlling pancreas ontogeny. Int J Dev Biol 52:823-835

22. D'Amour KA, Agulnick AD, Eliazer S, Kelly OG, Kroon E, Baetge EE (2005) Efficient differentiation of human embryonic stem cells to definitive endoderm. Nat Biotechnol 23:15341541
23. Van Hoof D, D'Amour KA, German MS (2009) Derivation of insulin-producing cells from human embryonic stem cells. Stem Cell Res 3:73-87

24. Du A, Hunter CS, Murray J et al (2009) Islet-1 is required for the maturation, proliferation, and survival of the endocrine pancreas. Diabetes 58:2059-2069

25. Aguilar-Bryan L, Bryan J, Nakazaki M (2001) Of mice and men: K(ATP) channels and insulin secretion. Recent Prog Horm Res $56: 47-68$

26. Gopel S, Zhang Q, Eliasson L et al (2004) Capacitance measurements of exocytosis in mouse pancreatic alpha-, beta- and deltacells within intact islets of Langerhans. J Physiol 556:711-726

27. Satin LS (2000) Localized calcium influx in pancreatic beta-cells: its significance for $\mathrm{Ca}^{2+}$-dependent insulin secretion from the islets of Langerhans. Endocrine 13:251-262

28. Schuit FC (1996) Factors determining the glucose sensitivity and glucose responsiveness of pancreatic beta cells. Horm Res 46:99106

29. Wang Z, Thurmond DC (2009) Mechanisms of biphasic insulingranule exocytosis - roles of the cytoskeleton, small GTPases and SNARE proteins. J Cell Sci 122:893-903

30. Rezania A, Riedel MJ, Wideman RD et al (2010) Production of functional glucagon-secreting alpha cells from human embryonic stem cells. Diabetes 60:239-247

31. Petri A, Ahnfelt-Ronne J, Frederiksen KS et al (2006) The effect of neurogenin 3 deficiency on pancreatic gene expression in embryonic mice. J Mol Endocrinol 37:301-316

32. Pirila E, Ramamurthy NS, Sorsa T, Salo T, Hietanen J, Maisi $P$ (2003) Gelatinase A (MMP-2), collagenase-2 (MMP-8), and laminin-5 gamma2-chain expression in murine inflammatory bowel disease (ulcerative colitis). Dig Dis Sci 48:93-98

33. Aye T, Toschi E, Sharma A, Sgroi D, Bonner-Weir S (2010) Identification of markers for newly formed beta-cells in the perinatal period: a time of recognized beta-cell immaturity. J Histochem Cytochem 58:369-376

34. Michael J, Carroll R, Swift HH, Steiner DF (1987) Studies on the molecular organization of rat insulin secretory granules. J Biol Chem 262:16531-16535

35. Suckale J, Solimena M (2010) The insulin secretory granule as a signaling hub. Trends Endocrinol Metab 21:599-609

36. MacDonald PE, Wheeler MB (2003) Voltage-dependent $\mathrm{K}(+)$ channels in pancreatic beta cells: role, regulation and potential as therapeutic targets. Diabetologia 46:1046-1062

37. De Vos A, Heimberg H, Quartier E et al (1995) Human and rat beta cells differ in glucose transporter but not in glucokinase gene expression. J Clin Invest 96:2489-2495

38. Navarro-Tableros V, Fiordelisio T, Hernandez-Cruz A, Hiriart M (2007) Physiological development of insulin secretion, calcium channels, and GLUT2 expression of pancreatic rat beta-cells. Am J Physiol Endocrinol Metab 292:E1018-E1029

39. Rozzo A, Meneghel-Rozzo T, Delakorda SL, Yang SB, Rupnik M (2009) Exocytosis of insulin: in vivo maturation of mouse endocrine pancreas. Ann N Y Acad Sci 1152:53-62

40. Aguayo-Mazzucato C, Koh A, El Khattabi I et al (2011) Mafa expression enhances glucose-responsive insulin secretion in neonatal rat beta cells. Diabetologia 54:583-593

41. Spigelman AF, Dai X, MacDonald PE (2010) Voltage-dependent $\mathrm{K}(+)$ channels are positive regulators of alpha cell action potential generation and glucagon secretion in mice and humans. Diabetologia 53:1917-1926

42. MacDonald PE, Wang X, Xia F et al (2003) Antagonism of rat betacell voltage-dependent $\mathrm{K}^{+}$currents by exendin 4 requires dual activation of the $\mathrm{cAMP} /$ protein kinase $\mathrm{A}$ and phosphatidylinositol 3-kinase signaling pathways. J Biol Chem 278:52446-52453

43. Villasenor A, Chong DC, Cleaver O (2008) Biphasic Ngn3 expression in the developing pancreas. Dev Dyn 237:3270-3279 
44. Herrera PL, Nepote V, Delacour A (2002) Pancreatic cell lineage analyses in mice. Endocrine 19:267-278

45. Artner I, Blanchi B, Raum JC et al (2007) MafB is required for islet beta cell maturation. Proc Natl Acad Sci USA 104:3853-3858

46. Kelly OG, Chan MY, Martinson LA et al (2011) Cell-surface markers for the isolation of pancreatic cell types derived from human embryonic stem cells. Nat Biotechnol 29:750-756

47. Thorel F, Nepote V, Avril I et al (2010) Conversion of adult pancreatic alpha-cells to beta-cells after extreme beta-cell loss. Nature 464:1149-1154
48. Habener JF, Kemp DM, Thomas MK (2005) Minireview: transcriptional regulation in pancreatic development. Endocrinology 146:1025-1034

49. Gefen-Halevi S, Rachmut IH, Molakandov K et al (2010) NKX6.1 promotes PDX-1-induced liver to pancreatic beta-cells reprogramming. Cell Reprogram 12:655-664

50. Gauthier BR, Gosmain Y, Mamin A, Philippe J (2007) The beta-cell specific transcription factor Nkx6.1 inhibits glucagon gene transcription by interfering with Pax6. Biochem J 403:593-601 